\title{
Correlation of carbon isotope events in the Danish Upper Cretaceous chalk
}

\author{
Niels H. Schovsbo, Susanne Lil Rasmussen, Emma Sheldon and Lars Stemmerik
}

A high resolution carbon isotope $\left(\delta^{13} \mathrm{C}\right)$ profile through the upper Campanian to Maastrichtian chalk was recently completed based on material from the Stevns-1 core from the Stevns peninsula, eastern Denmark. The $\delta^{13} \mathrm{C}$ variation of marine carbonates essentially reflects global perturbations in the carbon cycle, i.e. the burial fluxes of carbonate carbon versus organic carbon. It is widely observed that the $\delta^{13} \mathrm{C}$ variation broadly tracks the eustatic sea-level curve, and that $\delta^{13} \mathrm{C}$ curves can be used for stratigraphic correlation (e.g. Jarvis et al. 2002). In the Stevns-1 core, a total of 29 notable isotope changes have been identified in the upper Campanian to Maastrichtian succession. In order to evaluate the stratigraphic significance of the isotope changes, the variation in $\delta^{13} \mathrm{C}$ values of the mid-Maastrichtian chalk from cores in eastern Denmark and the Danish North Sea, and from outcrops at Rørdal, northern Jylland has been examined (Fig. 1). The selected interval is characterised by distinct chalk and marl cycles in the Stevns- 1 and Karlslunde- 1 cores and in the Rørdal quarry (Fig. 2), whereas a non-cyclic clean chalk is found in the M-10X well from the North Sea. In the Rørdal quarry, the chalk-marl unit spans the upper-lower Maastrichtian boundary in the Boreal brachiopod and belemnite stratigraphies (Surlyk 1984; unpublished data, B. Lauridsen $\&$ F. Surlyk). In Stevns-1 and Karlslunde-1 the chalk-marl unit was deposited during the younger part of nannofossil subzone UC20b (Sheldon 2006, in press).

This paper presents preliminary results of a high-resolution study of carbon isotopes, carried out by the Geological Survey of Denmark and Greenland (GEUS) in co-operation with partners from the Department of Geography and Geology at the University of Copenhagen. This paper is a product of the Cretaceous Research Centre (CRC) at Geocenter Denmark.
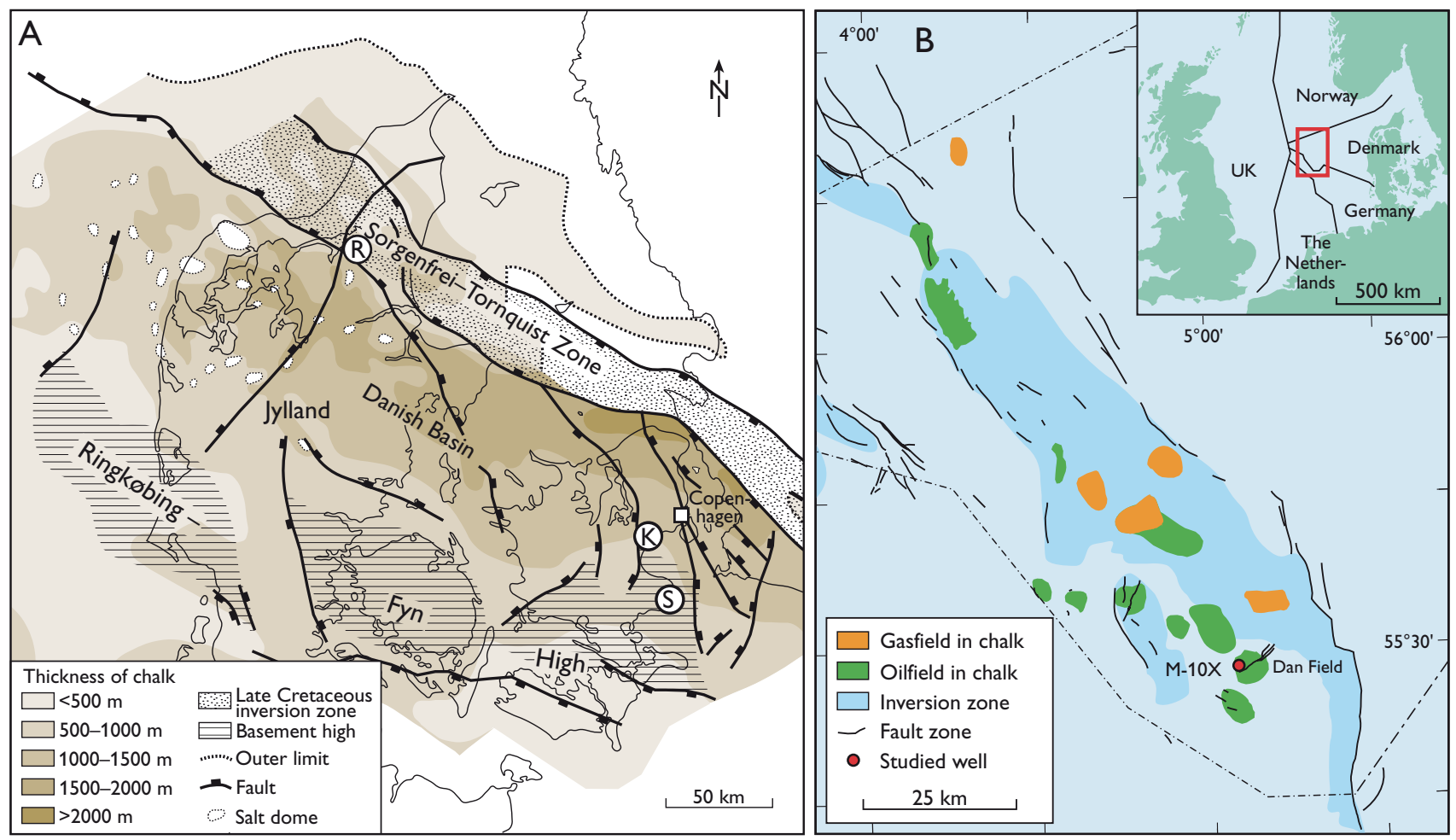

Fig. 1. A: Thickness of the Upper Cretaceous to Danian carbonates in the Danish area. $\mathbf{K}$, Karlslunde-1 borehole; $\mathbf{S}$, Stevns-1 borehole; $\mathbf{R}$, Rørdal quarry. Modified from Stemmerik et al. (2006). B: Location of the M-10X well and the dominant Late Cretaceous structural elements in the Danish Central Graben (modified from Ineson et al. 2006). The inset shows the territorial borders in the North Sea. 


\section{Stevns-1 carbon isotope curve}

The Stevns-1 borehole represents the first continuously cored Maastrichtian section in north-western Europe (Stemmerik et al. 2006). The borehole is located close to the Stevns Klint coastal cliff section (Fig. 1) and penetrated $456.1 \mathrm{~m}$ of Lower Danian bryozoan limestone and uppermost Maastrichtian to Campanian chalk with 100\% core recovery. The Campanian to Maastrichtian chalk is composed of very pure carbonate (90-95\%) and consists mainly of coccoliths. Marl beds $(1-10 \mathrm{~cm}$ thick) occur in two intervals, in the Campanian to Maastrichtian boundary interval and within the midMaastrichtian. The $\delta^{13} \mathrm{C}$ values in the Stevns-1 core have been measured on bulk sediment samples collected with a density of approximately four samples per metre. Isotope measurements were made at the Department of Geography and Geology. The analytical precision of the $\delta^{13} \mathrm{C}$ values is better than $\pm 0.05 \%$. All carbon isotope results are given relative to the V-PDB standard.

The mid-Maastrichtian marl succession in Stevns-1, from 90-110 m, forms part of a $120 \mathrm{~m}$ thick interval characterised by high $\delta^{13} \mathrm{C}$ values that range between 2.2 and $2.5 \%$ (Fig. $3)$. The interval is characterised by a gentle upward decrease in $\delta^{13} \mathrm{C}$ values terminated by a marked fall at $85 \mathrm{~m}$, near the boundary between the nannofossil subzones UC20b and UC20c. The overlying chalk, referred to subzone UC20c, is characterised by lower and more variable $\delta^{13} \mathrm{C}$ values between 1.7 and $2.2 \%$, and shows a general fall towards a distinct low at the UC20c-d boundary (Fig. 3). Within the interval from $135 \mathrm{~m}$ to $60 \mathrm{~m}$ in Stevns-1, we have defined seven conspicu- ous isotope events in chalk belonging to subzones UC20b and UC20c (Fig. 3). The three lower events, UC20b1-UC20b3, all predate the onset of marl deposition. Isotope event UC20b1, at $131 \mathrm{~m}$, is characterised by a slight increase in $\delta^{13} \mathrm{C}$ values followed by a decrease of $0.2 \%$. $\mathrm{UC20b} 2$, at $118 \mathrm{~m}$, is reflected by a change in $\delta^{13} \mathrm{C}$ values of $0.2 \%$. UC20b3 occurs immediately prior to the onset of marl deposition and is characterised by two short-term fluctuations in $\delta^{13} \mathrm{C}$ values of $0.2 \%$ each. The upper six events all post-date the marly interval. UC20c1, near the boundary between subzones UC20b and UC20c, is characterised by a drop in $\delta^{13} \mathrm{C}$ values and marks the termination of the early Maastrichtian $\delta^{13} \mathrm{C}$ high. Similarly UC20d1 is characterised by a marked fall in $\delta^{13} \mathrm{C}$ values immediately above the boundary between subzones UC20c and UC20d (Fig. 3). Isotope event $\mathrm{UC} 20 \mathrm{c} 2$, at $72 \mathrm{~m}$, is characterised by a change in $\delta^{13} \mathrm{C}$ values of $0.2 \%$. UC20c3, at $68 \mathrm{~m}$, is reflected by a decrease in $\delta^{13} \mathrm{C}$ values of $0.3 \%$ and UC20c4 is characterised by a $0.3 \%$ increase in $\delta^{13} \mathrm{C}$ values.

\section{Correlation to adjacent areas}

Carbon isotope data also have been aquired from the Maastrichtian chalk of the $250 \mathrm{~m}$ long Karlslunde-1 core (eastern Sjælland), from mid-Maastrichtian chalk and marl from the Rørdal quarry (Fig. 3), and from upper Maastrichtian chalk from the M-10X well in the Danish North Sea (Figs 1, 3).

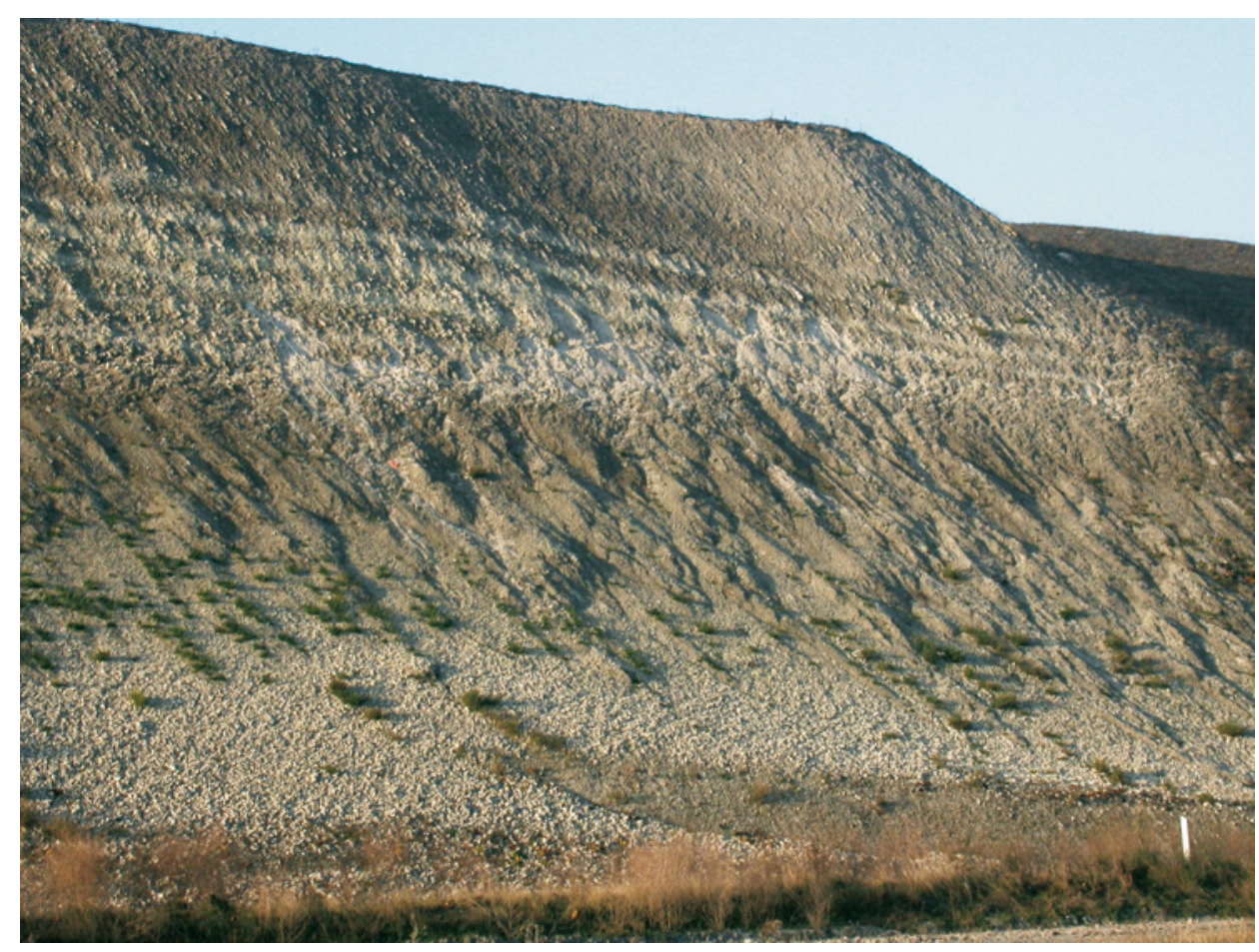

Fig. 2. Chalk and cyclical chalk-marl succession spanning the macrofossil defined lower-upper Maastrichtian boundary exposed in the Rørdal quarry. The exposed section consists of a lower homogeneous chalk unit, a middle cyclic chalk-marl unit and an upper unit of homogeneous chalk. The light beds are marl and the darker beds chalk. This 'inversion' of colour is due to surface weathering. The height of the section is $20 \mathrm{~m}$. 


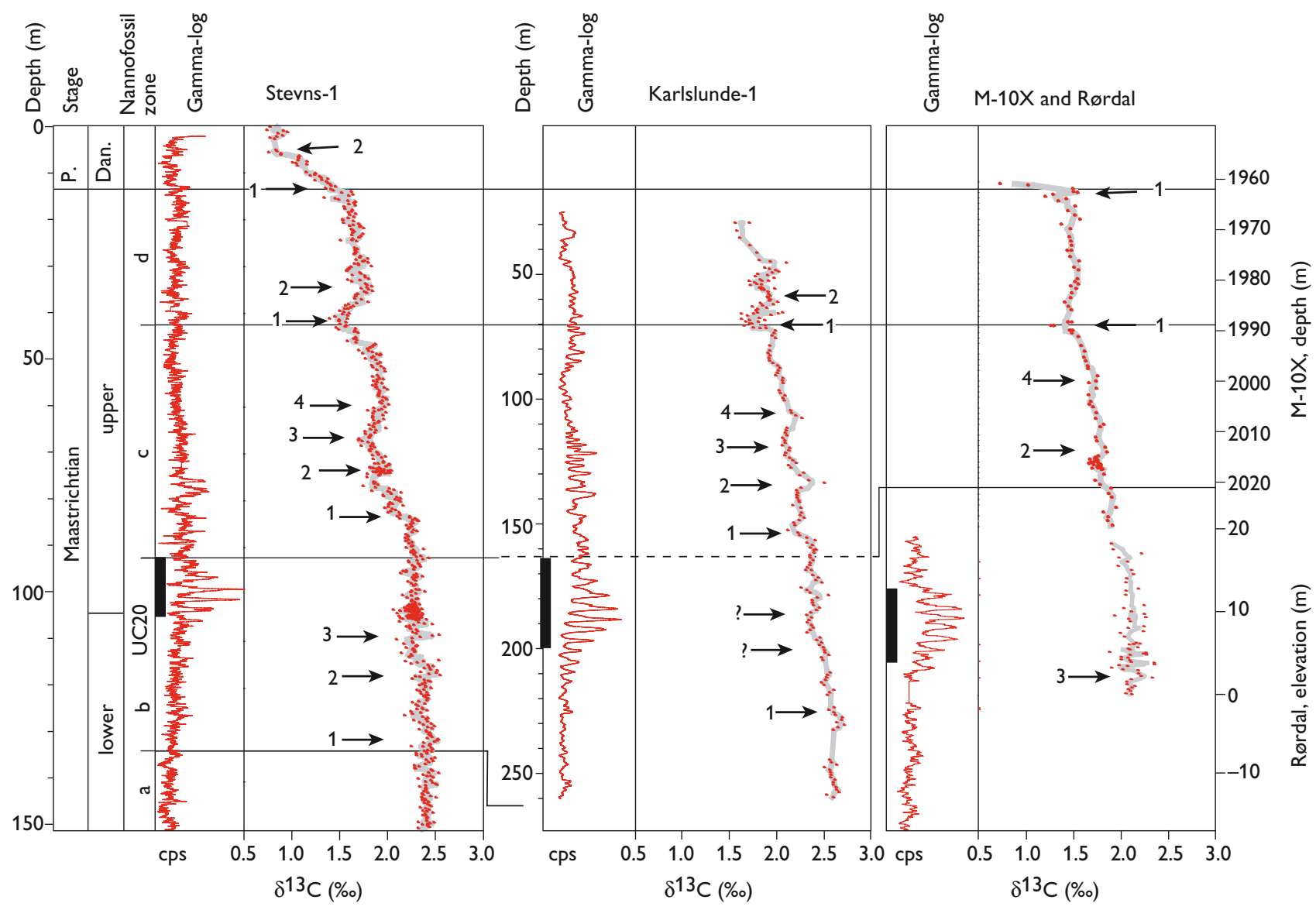

Fig. 3. Gamma-ray log and carbon isotope variation of the Stevns-1, the Karlslunde-1 and the M-10X (gamma-ray log not shown) and the Rørdal section (gamma-log for Stevns-1 obtained from core scanning (Stemmerik et al. 2006)). The thick black vertical lines indicate recognised cyclic chalk-marl intervals. The full black horizontal lines represent correlation based on nannofossils (Sheldon 2006). The stippled line shows the uncertain position of the nannofossil boundary. The thick grey lines represent running average of the data points. Note the difference in vertical scale between the wells. 11 marked isotope changes out of the 29 changes occur in the depicted interval. P, Paleocene; Dan, Danian; cps, counts per second.

Sedimentological and log data indicate that cyclically deposited chalk and marl are present in UC20b in both Stevns- 1 and Karlslunde- 1 . The $\delta^{13} \mathrm{C}$ curve for Karlslunde-1, although less densely sampled, displays the same overall pattern as the Stevns- 1 curve with an overall decrease in the $\delta^{13} \mathrm{C}$ values during the Maastrichtian, starting with a stable early Maastrichtian high followed by an interval with more fluctuating $\delta^{13} \mathrm{C}$ values (Fig. 3). Isotope events UC20c1-4 and UC20d1-2 are also easily identified in the Karlslunde- 1 succession whereas it has only been possible to identify the lowermost UC20b1 event in the interval below the chalk-marl cycles (Fig. 3). The $\delta^{13} \mathrm{C}$ values in Karlslunde-1 are approximately $0.1 \%$ higher than those in Stevns-1.

In the Rørdal section it has been possible to identify isotope event UC20b3 immediately below an interval of interbedded chalk and marl of mid-Maastrichtian age. At Rørdal, UC20b3 is characterised by short-term changes of $0.2 \%$ in the $2-6 \mathrm{~m}$ interval (Fig. 3). The $\delta^{13} \mathrm{C}$ values are approximately $0.2 \%$ o more negative than those from the Stevns-1 core.
The upper Maastrichtian chalk in the M-10X well was deposited in relatively deep water and differs from the timeequivalent onshore successions by the absence of flint nodules and layers (Ineson et al. 2006). We have identified isotope events UC20c2, UC20c4 and UC20d1 in the cored interval (Fig. 3). The UC20d1 event at $1990 \mathrm{~m}$ ends a long-term fall in $\delta^{13} \mathrm{C}$ values similar to those recognised in Stevns- 1 and Karlslunde-1 (Fig. 3). The absolute $\delta^{13} \mathrm{C}$ values are approximately $0.2 \%$ more negative than those recorded in Stevns- 1 . Isotope events UC20c2 and UC20c4 are both identified as short-term positive $\delta^{13} \mathrm{C}$ excursions of $0.1-0.2 \%$, similar to those seen in Stevns-1 and Karlslunde-1.

\section{Variation in sedimentation rates}

The correlation of $\delta^{13} \mathrm{C}$ events across the Danish area allows a refined stratigraphic subdivision of the chalk compared with the present nannofossil zonation, and thus leads to a more detailed model of sedimentation rates across the region. 
The present data set indicates that the accumulation rate in the Karlslunde area was almost twice as high as at Stevns-1 during subzone UC20c. The interval starting at UC20c1 and terminating at UC20d1 is $45 \mathrm{~m}$ thick in Stevns- 1 and $80 \mathrm{~m}$ thick in Karlslunde-1. In both cores the sediment consists of flint-rich chalk. Surprisingly, sedimentation rates for the upper Maastrichtian in the North Sea offshore area seem not to differ much from those recorded in the Stevns-1 core. The interval from UC20c2 to UC20d1 is $25 \mathrm{~m}$ in M-10X and $35 \mathrm{~m}$ in Stevns-1, and the thickness of the interval from UC20d1 to the Maastrichtian-Danian boundary is approximately $25 \mathrm{~m}$ in both areas.

\section{Lateral variation of carbon isotopes}

The $\delta^{13} \mathrm{C}$ values in the cyclic chalk-marl interval in Stevns-1 and Karlslunde- 1 show variations of up to $0.2 \%$, with a mean value of $2.3 \%$. In the Rørdal quarry, the $\delta^{13} \mathrm{C}$ values in the time-equivalent interval also show variations of $0.2 \%$, but the mean value is $2.1 \%$. Similarly, the average $\delta^{13} \mathrm{C}$ value of the chalk belonging to nannofossil subzone UC20c in M$10 \mathrm{X}$ is $0.2 \%$ o lower than that of the time-equivalent chalk in Stevns- 1 and Karlslunde-1. This east-west, intra-basinal variation in $\delta^{13} \mathrm{C}$ values most likely reflects compositional differences of the chalk, being richer in macrofossils towards the east.

\section{Conclusions}

The high-resolution carbon isotope curve constructed for the upper Campanian to uppermost Maastrichtian chalk in Stevns-1 allows 29 isotope events to be identified. The regional significance of eight of these events has been tested using isotope data from onshore and offshore cores and an outcrop. Most isotope events are readily identified in the wells and sections though they are generally less densely sampled. It is evident that $\delta^{13} \mathrm{C}$ data can be used for correlation of chalk at nannofossil subzone level, and give a better understanding of lateral variations in sedimentation rates.

\section{Acknowledgement}

The Danish Natural Science Research Council supported the project financially.

\section{References}

Ineson, J.R., Buchardt, B., Lassen, S., Rasmussen, J.A., Schiøler, P., Schovsbo, N.H., Sheldon, E. \& Surlyk, F. 2006: Stratigraphy and palaeoceanography of upper Maastrichtian chalks, southern Danish Central Graben. Geological Survey of Denmark and Greenland Bulletin 10, 9-12

Jarvis, I., Mabrouk, A., Moody, R.T.J. \& de Cabrera, S. 2002: Late Cretaceous (Campanian) carbon isotope events, sea-level change and correlation of the Tethyan and Boreal realms. Palaeogeography, Palaeoclimatology, Palaeoecology 188, 215-248.

Sheldon, E. 2006: Upper Maastrichtian-Danian nannofossils of the Danish Central Graben and the Danish Basin: a combined biostratigraphic-palaeoecological approach, 354 pp. Unpublished Ph.D. thesis, University College London, UK.

Sheldon, E. in press: Upper Campanian calcareous nannofossil biostratigraphy of the Stevns-1 borehole, Denmark. Journal of Nannoplankton Research 30

Stemmerik, L., Surlyk, F., Klitten, K., Rasmussen, S.L. \& Schovsbo, N. 2006: Shallow core drilling of the Upper Cretaceous Chalk at Stevns Klint, Denmark. Geological Survey of Denmark and Greenland Bulletin 10, 13-16.

Surlyk, F. 1984: The Maastrichtian stage in NW Europe, and its brachiopod zonation. Bulletin of the Geological Society of Denmark 33 , 217-223.

\section{Authors' addresses}

N.H.S., S.L.R. \& E.S., Geological Survey of Denmark and Greenland, Øster Voldgade 10, DK-1350 Copenhagen K, Denmark. E-mail: nsc@geus.dk L.S., Department of Geography and Geology, University of Copenhagen, Øster Voldgade 10, DK-1350 Copenhagen K, Denmark. 